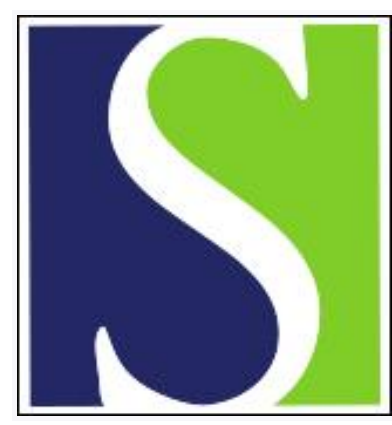

Scand J Work Environ Health 1996;22(3):165-175

https://doi.org/10.5271/sjweh.127

Issue date: Jun 1996

\title{
Occupation as a risk factor for knee disorders
}

by Kirkeskov Jensen L, Eenberg W

The following articles refer to this text: $2002 ; 28(1): 25-32$;

2003;29(4):270-279; 2004;30(4):261-278; 2011;37(1):37-44

Key terms: bursitis; chondromalacia; epidemiology; heavy physical work; knee osteoarthrosis; kneeling and squatting work; meniscal lesion; review

This article in PubMed: www.ncbi.nlm.nih.gov/pubmed/8837261 


\title{
Occupation as a risk factor for knee disorders
}

\author{
by Lilli Kirkeskov Jensen, MD,' Winnie Eenberg²
}

\begin{abstract}
Kirkeskov Jensen L, Eenberg W. Occupation as a risk factor for knee disorders. Scand J Work Environ Health 1996:22:165-75.

The objective of the present study was to review the literature on the risk of knee disorders in connection with kneeling or squatting work and heavy physical work. A systematic review of the literature revealed 19 controlled studies on this correlation: 16 on osteoarthrosis, 5 on bursitis, 3 on meniscal lesions, and 0 on chondromalacia. All the studies demonstrated a significantly increased prevalence of knee osteoarthrosis (all degrees) for subjects with kneeling or squatting work. The prevalence ratio in most of these studies was between 1.4 and 4. Four of eight studies demonstrated a significantly increased prevalence of knee osteoarthrosis in subjects with heavy physical work. The prevalence ratio in most of these studies was between 1.4 and 4.1. All the studies on bursitis showed an increased prevalence of bursitis in subjects with kneeling work. Occupational exposure could not be sufficiently documented as the cause of meniscal lesions and chondromalacia.
\end{abstract}

Key terms bursitis, chondromalacia, epidemiology, heavy physical work, knee osteoarthrosis, kneeling and squatting work, meniscal lesions, review.

Thus far investigations of the correlation between occupational risk factors and the development of diseases and trouble in the musculoskeletal system have mainly been limited to the lower back, neck, shoulders, and arms $(1,2)$.

Many occupations involve exposure of the knee joints during work, but health problems arising from such work loads have not received much attention. On the average, $19 \%$ of a population of Danish employees complained of knee trouble within the preceding 12 months. The frequency varied highly between occupational groups and was especially high, $32 \%$, for workers in the building trade (3). Osteoarthrosis of the knee has been radiologically demonstrated in $6 \%$ of an adult population aged between 35 and 74 years (4). The risk of developing knee osteoarthrosis depends on age, gender, weight, and sports activities together with exposure at work. The prevalence increases with age, from being negligible in subjects aged $25-34$ years to $20-40 \%$ in subjects aged 75 years or more $(4-8)$. The prevalence is higher for men than for women until the age of 45 years, whereafter it is higher for women (4).

Several investigations have shown a correlation between overweight and knee osteoarthrosis (4, 8-10). Sports may be a risk factor for the development of joint lesions, which are a well-known cause of osteoarthrosis
$(8,11,12)$. No certain correlation has been demonstrated between the various types of sport (eg, running, weightlifting and football) and the development of osteoarthrosis in subjects without previous major joint lesions (8).

The objective of this investigation was to review the literature on knee disorders and kneeling, squatting, and heavy physical work. The review concerns osteoarthrosis of the knee, bursitis, meniscal lesions, and chondromalacia.

\section{Materials and methods}

The relevant studies were identified in a search of computer-based data bases: MEDLINE, NIOSHTIC (a data base from the National Institute for Occupational Safety and Health), CISdoc, Embase and HSEline (the International Labour Organisation Occupational Health data bases). The key terms used were knee, meniscus, osteoarthrosis, osteoarthritis, bursitis, chondromalacia, work, and occupation.

In addition, literature on work and knee disorders was provided via a data base at the library of the Factory Inspectorate (Direktoratet for Arbejdstilsynet) in Denmark.

1 Clinic of Occupational Medicine, Glostrup Hospital, Glostrup, Denmark.

2 Copenhagen, Denmark.

Reprint requests to: Dr Lilli Kirkeskov Jensen, Malkehaven 13, DK-4330 Hvals $\varnothing$, Denmark. 
The material was evaluated on the basis of title and the reading of the abstracts. Studies were selected for a more-detailed review if they had a controlled design and they were carried out for one or several occupational groups; if they dealt with disorders of the knee (knee osteoarthrosis, bursitis, meniscal lesions or chondromalacia); if the study group had been exposed to kneeling, squatting, or heavy physical work (if the exposure was unclear from the title or the abstract, the works were procured and read); and if the works were published in English, German, or one of the Scandinavian languages. The references in the works procured were reviewed and selected with the same criteria.

The investigations were divided by the diagnoses as knee osteoarthrosis, bursitis, and meniscal lesion studies. We failed to find any relevant study on chondromalacia and occupation. Work involving a load on the knee was defined as kneeling or squatting work or heavy physical work. Studies in which the load was not detailed were classified according to experience, within occupational medicine, of whether the occupation was characterized by kneeling or squatting work or by heavy physical work. For some studies in which it was not stated, the prevalence ratio was calculated if the data were sufficient. For some studies we also calculated the P-value for the difference between the prevalences stated by using the Fisher exact test or the $\chi^{2}$-test.

With the key terms employed we obtained 585 references in NIOSHTIC, CISdoc, HSEline, EMbase and the data base of the Factory Inspectorate, and 314 references in MEDLINE. Among them 42 studies fulfilled our

Table 1. Methodological quality and results of the epidemiologic studies dealing with knee osteoarthrosis (all degrees), bursitis, and meniscal lesions. (Reference numbers in parentheses)

\begin{tabular}{|c|c|c|c|}
\hline & \multicolumn{3}{|c|}{ Methodological quality } \\
\hline & $\begin{array}{l}\text { Poor } \\
(\mathrm{N})\end{array}$ & $\begin{array}{l}\text { Medium } \\
\text { (N) }\end{array}$ & $\begin{array}{l}\text { Good } \\
(N)\end{array}$ \\
\hline \multicolumn{4}{|c|}{ Knee osteoarthrosis ${ }^{a}$} \\
\hline \multicolumn{4}{|c|}{ Kneeling and squatting } \\
\hline $\begin{array}{l}\text { Positive } \\
\text { Negative }\end{array}$ & $1(41)$ & $\begin{array}{l}5(39,40,42-44)^{b} \\
1(47)^{b}\end{array}$ & $3(38,45,46)^{c}$ \\
\hline \multicolumn{4}{|c|}{ Heavy physical work } \\
\hline $\begin{array}{l}\text { Positive } \\
\text { Negative }\end{array}$ & $1(49)$ & $\begin{array}{l}2(50-52) \\
2(47,48)\end{array}$ & $\begin{array}{l}1(53) \\
2(4,6)\end{array}$ \\
\hline \multicolumn{4}{|l|}{ Bursitis $^{a}$} \\
\hline $\begin{array}{l}\text { Positive } \\
\text { Negative }\end{array}$ & $1(41)$ & $2(42,54,55)$ & $2(38,56,57)$ \\
\hline \multicolumn{4}{|c|}{ Meniscal lesions ${ }^{\mathrm{a}}$} \\
\hline $\begin{array}{l}\text { Positive } \\
\text { Negative }\end{array}$ & $1(41)$ & $\begin{array}{l}1(58,59) \\
1(38)\end{array}$ & - \\
\hline
\end{tabular}

a Positive = significant positive association between work and outcome; negative $=$ no significant positive association between work and outcome.

- In one study the result was negative for one group and positive for another with kneeling work (42).

c Only one study positive in relation to knee osteophytes (38). criteria for a review. The studies referred to another 10 not revealed by the search. Exclusion was made of 15 studies dealing exclusively with self-reported knee trouble $(3,13-26)$, four studies without a reference group $(27-30)$, seven studies in which the design was not epidemiologic $(8,31-36)$, and one study dealing with an occupational group not exposed to knee load (37). Thus there remained 19 controlled studies with 25 references $(4,6,9,38-59)$. Several of the studies dealt with different types of knee disorders.

The methodological quality of each of the studies was systematically evaluated by methods adapted from Kristensen (60), Koes et al (61) and Sacks et al (62) and adjusted for the present review. The following five aspects of quality were evaluated for each study: (i) design and material (description of inclusion and exclusion criteria, size of the study group, description of participation rates, comparability of the study groups with respect to age, gender, height and weight, and healthy worker effect); (ii) potential confounding (age, gender, weight or body mass index, sport, traumas); (iii) measurement of outcome (clinical and paraclinical examination methods, blinded assessment); (iv) measurement of exposure (qualitative description, quantitative ergonomic observations); and ( $v$ ) data presentation and statistical analysis. Each item was scored and the quality of the study was assessed by the sum of the scores, the maximum being 15 points, and subdivided into "poor" studies ( $1-5$ points), "medium" quality studies (6-10 points), and "good" studies (11-15 points). Each study was evaluated independently by the authors. In case of disagreement on the final classification, a joint evaluation decided the classification.

\section{Results}

Table 1 presents the evaluation of the studies. The main shortcomings were no description of participation rates, small sample sizes, uncontrolled potential confounding, outcome assessments not blinded, and poor exposure description.

\section{Osteoarthrosis of the knee}

Altogether we found 16 studies on a correlation between knee osteoarthrosis and occupation. Among them, 13 were cross-sectional, two were case-referent in nature, and one was a historical follow-up study. Nine concerned occupations with predominantly kneeling or squatting work, and seven concerned occupations with heavy physical work. One study dealt with both kneeling and heavy physical work. 


\section{Kneeling or squatting work}

Eight studies demonstrated an increased prevalence of knee osteoarthrosis (all degrees), and one study showed an increased prevalence of knee-osteophytes (38) in occupations with kneeling or squatting work. Table 2 shows the distribution for the men. Only a very few studies gave results for women.

In the 1950s, Kellgren \& Lawrence $(9,39)$ and Lawrence (40) found an increased prevalence of radiologically determined knee osteoarthrosis among miners as compared with various reference groups without kneeling or squatting work.

Von Nauwald (41) compared 101 pipe fitters between 35 and 65 years of age and employed in the shipbuilding industry with a reference group of 74 subjects whose occupations did not involve kneeling. The participants were interviewed and physical and radiological examinations were performed. Knee osteoarthrosis was divided into three degrees of severity (grade $1-3$ ) using unspecified criteria. Mild to severe knee osteoarthrosis (grade $1-3$ ) was found in $78 \%$ of the pipe fitters and in $55 \%$ of the referents, and moderate to severe knee osteoarthrosis (grade $2-3$ ) was determined for $32 \%$ of the pipe fitters and $8 \%$ of the referents.
Thun et al (42) carried out a questionnaire study on 112 floor and carpet layers, 42 terrazzo setters, and 243 millwrights and bricklayers. The groups were divided by three degrees of knee load, grade 1 being kneeling work with use of a "knee kicker," a tool used to stretch the carpet for wall-to-wall installation (floor and carpet layers), grade 2 being kneeling work without using a knee kicker (terrazzo setters), and grade 3 being no kneeling work (millwright and bricklayers). One of the questions was "Have you ever had arthritis of the knee?" The prevalences were $14.3 \%$ for the floor and carpet layers, $25.7 \%$ for the terrazzo setters, and $12.9 \%$ for the millwrights and bricklayers.

Greinemann $(43,44)$ examined 500 miners 50 years of age who had been working for at least 25 years and 500 referents 50 years of age who had not been exposed to knee load either at work or in their leisure-time activities. Knee osteoarthrosis was radiologically determined for $13 \%$ of the miners and $1 \%$ of the referents.

Anderson \& Felson (4) employed data from HANES I, an American population survey of 5193 subjects from 1971 to 1975 . Subjects 35 to 64 years of age, totaling 4011 (of whom 1853 were men) were divided by occupation and classified according to occupation involving kneeling, squatting or crawling postures. The data on

Table 2. Osteoarthrosis of the knee (\%) and occupations with kneeling and squatting work among men. ${ }^{\mathrm{a}}$

\begin{tabular}{|c|c|c|c|c|c|c|c|c|c|c|c|}
\hline \multirow[t]{2}{*}{ Author } & \multirow[t]{2}{*}{ Outcome } & \multirow{2}{*}{\multicolumn{2}{|c|}{$\begin{array}{l}\text { Participants Age } \\
\text { (N) (years) }\end{array}$}} & \multirow[t]{2}{*}{ Type of work } & \multirow[t]{2}{*}{ Exposure } & \multicolumn{2}{|c|}{$\begin{array}{c}\text { Knee } \\
\text { osteoarthrosis } \\
\end{array}$} & \multicolumn{2}{|c|}{ Prevalence ratio } & \multicolumn{2}{|c|}{$\begin{array}{l}\text { Significant } \\
(P<0.05)\end{array}$} \\
\hline & & & & & & All & Severeb & All & Severeb & All & Severe $b$ \\
\hline $\begin{array}{l}\text { Kivimäki } \\
\text { et al (38) }\end{array}$ & $\begin{array}{l}\text { X-ray } \\
\text { grade } 1-4\end{array}$ & $\begin{array}{l}168 \\
146\end{array}$ & $25-49$ & $\begin{array}{l}\text { Floor and carpet laying } \\
\text { Painting }\end{array}$ & $\begin{array}{l}\text { Kneeling: carpet and floorlayers } \\
42 \% \text { and painters } 3 \%\end{array}$ & $\begin{array}{l}58^{c} \\
41\end{array}$ & $\begin{array}{l}2 \\
2\end{array}$ & $\begin{array}{l}1.4 \\
1.0\end{array}$ & $\begin{array}{l}1.0 \\
1.0\end{array}$ & Yes & No \\
\hline $\begin{array}{l}\text { Enderlein \& } \\
\text { Kasch } \\
(45,46)\end{array}$ & $\begin{array}{l}\text { X-ray and } \\
\text { clinical } \\
\text { grade } 1-3\end{array}$ & $\begin{array}{r}173 \\
77 \\
107 \\
116\end{array}$ & $18-65$ & $\begin{array}{l}\text { Welding } \\
\text { Shipbuilding } \\
\text { Pipe fitting } \\
\text { Shipyard work } \\
\text { without kneeling }\end{array}$ & $\begin{array}{l}\text { Keratoses on the knees: } \\
\text { welders } 75 \% \text {, shipbuilders } 30 \% \text {, } \\
\text { pipefitters } 10 \% \text {, } \\
\text { reference group } 0 \%\end{array}$ & $\begin{array}{l}74 \\
54 \\
52 \\
22\end{array}$ & $\frac{8}{2}$ & $\begin{array}{l}3.4 \\
2.5 \\
2.4 \\
1.0\end{array}$ & $\dot{.}$ & Yes & Yes \\
\hline $\begin{array}{l}\text { Anderson \& } \\
\text { Felson (4) }\end{array}$ & $\begin{array}{l}\text { X-ray } \\
\text { grade 2-4 }\end{array}$ & 1853 & $35-64$ & $\begin{array}{l}\text { Knee-bending work } \\
\text { No knee-bending work }\end{array}$ & $\begin{array}{l}\text { Categories of occupations } \\
\text { associated to no need for } \\
\text { kneeling and kneeling needed }\end{array}$ & $\mathrm{B}^{3}$ (all & ili) & $\begin{array}{l}0.9 \\
0.8 \\
2.5\end{array}$ & $\begin{array}{l}5-44 y)^{e} \\
5-54 y) \\
5-64 y)\end{array}$ & $\begin{array}{l}\text { No } \\
\text { No } \\
\text { Yes }\end{array}$ & . \\
\hline $\begin{array}{l}\text { Greinemann } \\
(43,44)\end{array}$ & $X$-ray & $\begin{array}{l}500 \\
500\end{array}$ & $\ln 50 \mathrm{~s}$ & $\begin{array}{l}\text { Mining } \\
\text { No knee-bending work }\end{array}$ & $\begin{array}{l}\text { At least } 25 \text { years under } \\
\text { ground compared with men } \\
\text { without knee-bending work }\end{array}$ & $\begin{array}{l}65 \\
16\end{array}$ & $\begin{array}{r}13 \\
1\end{array}$ & $\begin{array}{l}4.1 \\
1.0\end{array}$ & $\begin{array}{r}13.0 \\
1.0\end{array}$ & Yes & Yes \\
\hline $\begin{array}{l}\text { Thun et } \\
\text { al (42) }\end{array}$ & $\begin{array}{l}\text { Self- } \\
\text { reported }\end{array}$ & $\begin{array}{r}112 \\
42 \\
243\end{array}$ & $19-87$ & $\begin{array}{l}\text { Carpet and floor laying } \\
\text { Terrazzo setting } \\
\text { Millwrighting and } \\
\text { bricklayingd }\end{array}$ & $\begin{array}{l}\text { Kneeling with use of knee } \\
\text { kicker, kneeling and } \\
\text { seldom kneeling (employed } \\
1-60 \text { years) }\end{array}$ & $\begin{array}{l}14 \\
26 \\
13\end{array}$ & : & $\begin{array}{l}1.1 \\
2.0 \\
1.0\end{array}$ & $\dot{-}$ & $\begin{array}{l}\text { No } \\
\text { Yes }\end{array}$ & - \\
\hline $\begin{array}{l}\text { Von Nauwald } \\
\text { (41) }\end{array}$ & $\begin{array}{l}\text { X-ray } \\
\text { grade } 1-3\end{array}$ & $\begin{array}{r}101 \\
74\end{array}$ & $35-63$ & $\begin{array}{l}\text { Pipe fitting } \\
\text { No knee-bending work }\end{array}$ & $\begin{array}{l}\text { Kneeling and squatting, } \\
\text { on the average } 25 \text { years }\end{array}$ & $\begin{array}{l}78 \\
55\end{array}$ & $\begin{array}{r}32 \\
8\end{array}$ & $\begin{array}{l}1.4 \\
1.0\end{array}$ & $\begin{array}{l}4.0 \\
1.0\end{array}$ & Yes & Yes \\
\hline $\begin{array}{l}\text { Kellgren \& } \\
\text { Lawrence }(9)\end{array}$ & $\begin{array}{l}\text { X-ray } \\
\text { grade } 1-4\end{array}$ & $\begin{array}{l}74 \\
18 \\
81\end{array}$ & $55-64$ & $\begin{array}{l}\text { Mining } \\
\text { Cotton working } \\
\text { Otherd }^{d}\end{array}$ & $\begin{array}{l}\text { Persons associated with } \\
\text { the predominant occupation }\end{array}$ & $\begin{array}{l}42 \\
24 \\
20\end{array}$ & : & $\begin{array}{l}2.1 \\
1.2 \\
1.0\end{array}$ & i. & Yes & \\
\hline $\begin{array}{l}\text { Lawrence } \\
(40)\end{array}$ & $\begin{array}{l}\text { X-ray } \\
\text { grade } 1-4\end{array}$ & $\begin{array}{r}221 \\
54 \\
45 \\
42\end{array}$ & $41-50$ & $\begin{array}{l}\text { Mining } \\
\text { Docking } \\
\text { Light manual work } \\
\text { Sedentary workd }\end{array}$ & $\begin{array}{l}\text { Miners: kneeling and heavy } \\
\text { lifting } \\
\text { dockers: heavy lifting }\end{array}$ & $\begin{array}{l}47 \\
50 \\
24 \\
17\end{array}$ & $\begin{array}{r}5 \\
2 \\
4 \\
-\end{array}$ & $\begin{array}{l}2.8 \\
2.9 \\
1.4 \\
1.0\end{array}$ & $\dot{.}$ & Yes & No \\
\hline $\begin{array}{l}\text { Kellgren \& } \\
\text { Lawrence } \\
\text { (39) }\end{array}$ & $\begin{array}{l}\text { X-ray } \\
\text { grade } 1-4\end{array}$ & $\begin{array}{l}42 \\
45 \\
84\end{array}$ & $40-50$ & $\begin{array}{l}\text { Mining } \\
\text { Manuel work } \\
\text { Office Work }\end{array}$ & By occupation & $\begin{array}{l}46 \\
22 \\
24\end{array}$ & $\begin{array}{r}6 \\
2 \\
-\end{array}$ & $\begin{array}{l}1.9 \\
0.9 \\
1.0\end{array}$ & $\dot{.}$ & Yes & No \\
\hline
\end{tabular}

a In all the studies the design was cross-sectional.

Severe: knee osteoarthrosis grade $3-4$ or grade 3.

Knee osteophytes, not knee osteoarthrosis grade $1-4$.

Reference group in the study.

c Odds ratio used in the study ( $y=$ years). 
exposure were based on 400 occupational codes, of which 308 were represented in the study. The data correlated with X-ray findings in the knees evaluated according to the criteria of Kellgren \& Lawrence (63). There was a significantly increased prevalence of knee osteoarthrosis for the men [odds ratio (OR) 2.45] and the women (OR 3.49) aged 55-64 years who used kneeling, squatting, and crawling work postures. For the age groups under 55 years there were no certain differences.

In a cross-sectional study of shipyard workers, Enderlein \& Kasch $(45,46)$ examined 283 welders, 171 shipbuilders (stell millwrights), and 113 pipe fitters and a reference group of 168 persons aged 18 to 65 years. The material was grouped into subjects with and without previous knee trauma. Keratosis on the front of their knee was used as a measure of the degree of kneeling work. Among the pipe fitters, $10 \%$ had keratosis on the knees, as did $30 \%$ of the shipbuilders and $75 \%$ of the welders. No keratosis was found in the reference group. On the basis of the aggregated results from a physical and radiological examination, the degree of osteoarthrosis was classified on a scale from 0 (no knee osteoarthrosis) to 3 (severe knee osteoarthrosis).

There was an increased prevalence of knee osteoarthrosis, grade $1-3$, for the welders compared with the other groups. The prevalence of knee osteoarthrosis increased with increasing intensity and duration of exposure. Subjects with previous knee disorders had a higher prevalence, and knee osteoarthrosis occurred at an earlier age. The prevalences in table 2 are given for the group without previous knee disorders only.

In a cross-sectional study, Kivimäki et al (38) examined 168 carpet and floor layers and 146 painters (reference group) aged 25-49 years using questionnaires and a physical and radiological examination. Work practices were studied using video recordings of both occupational groups. The carpet and floor layers worked in a kneeling posture with one or both knees on the floor for $42 \%$ of the time. The painters used kneeling or squatting postures for less than $5 \%$ of the observed work hours. There were no differences between the groups as to severe knee osteoarthrosis according to the criteria of Kellgren \& Lawrence (63), but there was a significantly increased prevalence of knee osteophytes among the carpet and floor layers as compared with the painters.

\section{Heavy physical work}

Eight studies dealt with heavy physical work and knee osteoarthrosis (table 3). Four of these studies demonstrated an increased prevalence of knee osteoarthrosis in subjects with heavy physical work.

Lawrence et al (47) examined 294 foundry workers active as such for at least 10 years and aged 3574 years, and 287 age-matched referents from the general population. They found a prevalence of knee osteo- arthrosis, grade $1-4$, of $26 \%$ for the foundry workers and of $39 \%$ for the general population, the difference being significant.

Partridge \& Duthie (48) interviewed 206 dockers with heavy physical work and 138 referents. A clinical examination was made of all the subjects, and it revealed knee osteoarthrosis in $3.4 \%$ of the dockers and $2.2 \%$ of the referents.

The cross-sectional study by Wickström et al (6) comprised 252 active concrete reinforcement workers and 231 painters (reference group) aged 24-64 years. The participants were interviewed and underwent a physical and radiological examination. For the evaluation of the radiological findings, the material was divided into no, mild, moderate, and severe osteoarthrosis on the basis of consensus between two radiologists. In Wickström et al's study (6) the work practices of both groups were video-taped, and the results showed that the concrete reinforcement workers had more heavy lifts than the painters. The former group lifted loads weighing over $20 \mathrm{~kg}$ six times an hour, whereas the latter seldom lifted such loads. The painters worked in a squatting posture for $9 \%$ of the observed worktime and in a kneeling posture for $3 \%$ of the time, whereas the respective figures for the concrete reinforcement workers were $2 \%$ and $4 \%$.

$\mathrm{X}$ rays revealed osteophytes corresponding to the tibiofemoral joint in $18 \%$ of the concrete reinforcement workers and in $15 \%$ of the painters. Narrowing of the joint space was seen in $2 \%$ of both groups, and subchondral sclerosis was found in $2 \%$ of the concrete reinforcement workers and $1 \%$ of the painters. The prevalence of degenerative changes was $22 \%$ for the concrete reinforcement workers and $20 \%$ for the painters.

Lindberg \& Montgomery (49) examined the prevalence of knee osteoarthrosis in 332 men, mean age 66 years, with heavy physical work at a shipyard for more than 30 years. The "internal" reference group consisted of 179 office workers from the shipyard and 173 male teachers, the "external" reference group of 438 age-matched subjects from the general population. A knee X ray was performed for the subjects in the study group and evaluated with regard to knee osteoarthrosis using the criteria of Ahlbäck (64). Knee osteoarthrosis was found in $3.9 \%$ of the shipyard workers, $1.4 \%$ of the "internal" reference group, and $1.6 \%$ of the "external" reference group. The difference was significant.

In the previously mentioned HANES I study by Anderson \& Felson (4) the material was divided into subjects with and without heavy physical work. Among 4011 subjects between 35 and 64 years of age they found a significantly increased prevalence of knee osteoarthrosis among women with heavy physical work in the age group 55-64 years (OR 3.1). The prevalence was likewise increased for the men with heavy physical work in 
Table 3. Osteoarthrosis of the knee (\%) and occupations with heavy physical work. All studies not deemed otherwise were cross-sectional.

\begin{tabular}{|c|c|c|c|c|c|c|c|c|c|c|c|}
\hline \multirow[t]{2}{*}{ Author } & \multirow[t]{2}{*}{ Outcome } & \multirow[t]{2}{*}{$\begin{array}{l}\text { Participants } \\
\text { (N) }\end{array}$} & \multirow[t]{2}{*}{$\begin{array}{c}\text { Age } \\
\text { (years) }\end{array}$} & \multirow[t]{2}{*}{ Type of work } & \multirow[t]{2}{*}{ Exposure } & \multicolumn{2}{|c|}{$\begin{array}{c}\text { Knee } \\
\text { osteoarthrosis } \\
\end{array}$} & \multicolumn{2}{|c|}{ Prevalence ratio } & \multicolumn{2}{|c|}{$\begin{array}{l}\text { Significant } \\
(P<0.05) \\
\end{array}$} \\
\hline & & & & & & All & Severe ${ }^{\mathrm{a}}$ & All & Severe & All & Severe $^{a}$ \\
\hline $\begin{array}{l}\text { Vingård et } \\
\text { al }(53)^{\text {b,c }}\end{array}$ & $\begin{array}{l}\text { Hospital } \\
\text { diagnosis }\end{array}$ & $\begin{array}{l}521 \text { knee } \\
\text { osteoarthrosis } \\
207317 \text { referents }\end{array}$ & $36-78$ & $\begin{array}{l}\text { High exposure work } \\
\text { Low exposure work } \\
\text { (blue-collar workers) }\end{array}$ & $\begin{array}{l}\text { High or low exposure to } \\
\text { dynamic or static forces } \\
\text { on the lower extremity } \\
\text { at least for } 10 \text { years }\end{array}$ & . & $\dot{.}$ & : & $\begin{array}{l}1.2(1905-24)^{d} \\
1.4(1925-45)^{d}\end{array}$ & . & $\begin{array}{l}\text { No } \\
\text { Yes }\end{array}$ \\
\hline $\begin{array}{l}\text { Vingård et } \\
\text { al }(51,52)^{b . t}\end{array}$ & $\begin{array}{l}\text { Diagnosis } \\
\text { disability } \\
\text { pension }\end{array}$ & $\begin{array}{l}181 \text { knee } \\
\text { osteoarthrosis } \\
298 \text { referents }\end{array}$ & $45-69$ & $\begin{array}{l}\text { High exposure work } \\
\text { Low exposure worke }\end{array}$ & $\begin{array}{l}\text { High or low load on the } \\
\text { lower extremity }\end{array}$ & . & . & & 14.3 & . & Yes \\
\hline $\begin{array}{l}\text { Kohatsu \& } \\
\text { Schurman } \\
(50)^{b, i}\end{array}$ & $\begin{array}{l}X \text {-ray } \\
\text { grade 3-4 }\end{array}$ & $\begin{array}{l}46 \text { severe knee } \\
\text { osteoarthrosis } \\
46 \text { referents }\end{array}$ & $\begin{array}{c}71 \\
\text { (mean) }\end{array}$ & $\begin{array}{l}\text { Moderate to heavy } \\
\text { work } \\
\text { Age-matched } \\
\text { community referentse }\end{array}$ & $\begin{array}{l}\text { Self-reported light, moder- } \\
\text { ate, heavy or very heavy } \\
\text { work }\end{array}$ & - & . & . & $2.3-3.4$ & . & Yes \\
\hline $\begin{array}{l}\text { Anderson \& } \\
\text { Felson (4) }\end{array}$ & $\begin{array}{l}X \text {-ray } \\
\text { grade 2-4 }\end{array}$ & 1853 & $35-64$ & $\begin{array}{l}\text { Physical demanding } \\
\text { work } \\
\text { Not physical } \\
\text { demanding work }\end{array}$ & $\begin{array}{l}\text { Categories of occupations } \\
\text { associated with physical } \\
\text { demands in the job }\end{array}$ & . & $\dot{.}$ & $\begin{array}{l}0.9 \\
(35- \\
1.1 \\
(45- \\
3.1 \\
(55-\end{array}$ & $\begin{array}{l}4 \text { years }^{d} \\
4 \text { years) }^{d} \\
4 \text { years }^{d}\end{array}$ & $\begin{array}{l}\text { No } \\
\text { No } \\
\text { No }\end{array}$ & . \\
\hline $\begin{array}{l}\text { Lindberg \& } \\
\text { Montgomery } \\
\text { (49) }\end{array}$ & $\begin{array}{l}\text { X-ray } \\
\text { severe }\end{array}$ & $\begin{array}{l}332 \\
352 \\
438\end{array}$ & $\begin{array}{c}66 \\
\text { (mean) }\end{array}$ & $\begin{array}{l}\text { Shipyard work } \\
\text { Office work and } \\
\text { teaching } \\
\text { General population }\end{array}$ & $\begin{array}{l}\text { Heavy work in a shipyard } \\
\text { for more than } 30 \text { years }\end{array}$ & . & $\begin{array}{l}3.9 \\
1.4 \\
1.6\end{array}$ & . & $\begin{array}{l}2.4 \\
0.9 \\
1.0\end{array}$ & . & $\begin{array}{c}\text { Yes } \\
\cdot \\
\cdot\end{array}$ \\
\hline $\begin{array}{l}\text { Wickström et } \\
\text { al }(6)\end{array}$ & $\begin{array}{l}\text { X-ray, } \\
\text { all } \\
\text { degrees }\end{array}$ & $\begin{array}{l}252 \\
231\end{array}$ & $20-64$ & $\begin{array}{l}\text { Reinforcement work } \\
\text { Paintinge }\end{array}$ & $\begin{array}{l}\text { Lifting loads over } 20 \mathrm{~kg} \text { : } \\
\text { six times an hour for re- } \\
\text { inforcement workers and } \\
\text { seldom for painters; work } \\
\text { experience } 15 \text { years (mean) }\end{array}$ & $\begin{array}{l}22 \\
20 \\
\end{array}$ & $\begin{array}{l}2.0 \\
2.0\end{array}$ & $\begin{array}{l}1.1 \\
1.0\end{array}$ & $\begin{array}{l}1.0 \\
1.0\end{array}$ & No & No \\
\hline $\begin{array}{l}\text { Partridge \& } \\
\text { Duthie (48) }\end{array}$ & Clinical & $\begin{array}{l}206 \\
138\end{array}$ & $25-64$ & $\begin{array}{l}\text { Docking } \\
\text { Civil servant work }\end{array}$ & $\begin{array}{l}\text { High physical effort, } \\
\text { no physical effort }\end{array}$ & . & $\begin{array}{l}3.4 \\
2.2\end{array}$ & . & $\begin{array}{l}1.6 \\
1.0\end{array}$ & ; & No \\
\hline $\begin{array}{l}\text { Lawrence et } \\
\text { al (47) }\end{array}$ & $\begin{array}{l}X \text {-ray } \\
\text { grade } 1-4\end{array}$ & $\begin{array}{l}294 \\
287\end{array}$ & $45-74$ & $\begin{array}{l}\text { Foundry work } \\
\text { Random sample of } \\
\text { general populatione }\end{array}$ & $\begin{array}{l}\text { Heavy work under hot } \\
\text { conditions }\end{array}$ & $\begin{array}{l}26 \\
39\end{array}$ & $\begin{array}{l}1.4 \\
3.1\end{array}$ & $\begin{array}{l}0.7 \\
1.0\end{array}$ & $\begin{array}{l}0.5 \\
1.0\end{array}$ & No & No \\
\hline
\end{tabular}

Severe: knee osteoarthrosis grade $3-4$ or grade 3 .

- Design not cross-sectional.

c Design was that of a historical follow-up.

Odds ratio or relative risk used in the study.

Reference group in the study.

Case-referent study.

the age group 55-64 years (OR 1.88), but the difference was not significant. No correlation was found in the younger age groups.

The questionnaire study by Kohatsu \& Schurman (50) comprised 138 patients who had undergone total knee arthroplasty owing to osteoarthrosis during the period 1977-1988. Among those who answered the questionnaire, a selection was made of patients over 55 years with radiologically demonstrated knee osteoarthrosis, grade 3-4 according to the criteria of Kellgren \& Lawrence (63). These subjects were compared with agematched referents from the general population without knee osteoarthrosis. The subjects comprised 46 patients and 46 referents. The questions concerning work load distinguished between light, moderate, heavy, or very heavy physical work. Previous knee trauma was reported by $64 \%$ of the patients and $22 \%$ of the referents. Heavy work was reported two to three times more often by the patients than by the referents.

Using a case-referent design, Vingård et al $(51,52)$ investigated 1307 men from the Stockholm area who were born between 1915 and 1934 or who were assigned an early retirement pension in $1979,1980,1981$, and
1984 because of low-back trouble, shoulder and neck trouble, or hip or knee osteoarthrosis. It was not stated how the diagnoses were made. A comparison as to occupation and exposure was made between the 181 patients with knee osteoarthrosis and 298 men from the general population. On the basis of occupational codes four experts classified the degree of static and dynamic impact loads on the knees within the individual occupations and the material was divided into occupational groups with low, moderate, and high exposure.

In Vingård et al's studies $(51,52)$ a comparison of subjects with high and low exposure showed a relative risk of 14.3 for early retirement pension owing to knee osteoarthrosis. In the group consisting of painters and floor layers, a combination that was not justified in the study, the relative risk of being assigned an early retirement pension owing to knee osteoarthrosis was 23.1.

Vingård et al (53) also performed a register-based cohort study (historical follow-up study). The study population consisted of subjects from 13 of 24 counties in Sweden and was drawn from a nationwide register of hospitalized subjects. Among the criteria were that the subjects be born between 1905 and 1945, that they re- 
mained in the same occupation through the period 1960 to 1970 ; and that they had been hospitalized for knee osteoarthrosis in the period 1981 to 1983. Exposure to dynamic and static impact loads on the knees were assessed for the individual occupations using the same methods as described for the author's studies $(51,52)$. The material was divided into subjects with high, moderate, and low exposure. The groups with high and low exposure were compared, whereas that with moderate exposure was excluded from the analyses.

As compared with the low-exposure group, men in the high exposure group of Vingård et al's study (53) had a risk ratio (RR) of 1.2 (men born between 1905 and 1924) and 1.4 (men born between 1925 and 1945) for knee osteoarthrosis. The difference was significant for the younger birth cohort. Male farmers, construction workers, and fire fighters had increased risks of hospital treatment due to osteoarthrosis of the knee (RR $2.5-$ $3.8)$.

\section{Bursitis}

We found five controlled studies on a correlation between occupation and bursitis (table 4).

Von Nauwald (41) performed a physical examination of 101 pipe fitters and 74 referents. Among the pipe fitters, bursitis was present in the right knee of $44 \%$ and in the left knee $36 \%$. Bursitis was not found in any of the referents.

Partridge et al (54) interviewed 858 workers at six foundries and found 14 cases of prepatellar bursitis among 169 floor molders (8.3\%), whose work involved kneeling, against five cases $(0.7 \%)$ among the remaining foundry workers without kneeling postures.

In the studies by Thun et al (42) and Tanaka et al (55), comprising 112 carpet and floor layers, 42 terrazzo setters, and 243 millwrights and bricklayers (reference group), previous bursitis was reported by $20 \%$ of the carpet and floor layers, $11 \%$ of the terrazzo setters, and $6 \%$ of the millwrights and bricklayers. The work of the carpet and floor layers involved kneeling and the use of knee kickers; that of the terrazzo setters involved kneeling but no use of knee kickers; and that of the millwrights and bricklayers involved neither kneeling nor the use of knee kickers.

In the questionnaire study by Kivimäki et al (38), of 168 floor and carpet layers and 146 painters, $19 \%$ of the floor and carpet layers reported that they had previously had prepatellar bursitis diagnosed by a physician, against $2 \%$ of the painters (reference group).

An ultrasonographic examination of a sample of the floor and carpet layers and of the painters in Kivimäki et al's study $(56,57)$ revealed changes in the prepatellar, the superficial, and the infrapatellar bursa in $49 \%$ of the floor and carpet layers and in $7 \%$ of the painters $(56,57)$. Fluid accumulation was present in the prepatellar or the superficial bursa in $5.8 \%$ of the floor and carpet layers and in none of the painters. Only the $5.8 \%$ of the floor and carpet layers with signs of acute bursitis (verified by fluid accumulation) reported knee pain. Ultrasonographically demonstrated changes in the bursa did not correlate with previously reported bursitis.

\section{Meniscal lesions}

Our search for relevant literature revealed nine references on meniscal lesions and occupation $(27,30,36,38$, $41,43,44,58,59)$. Only three studies, four references $(38,41,58,59)$ fulfilled our criteria of inclusion.

Sharrard \& Liddell (58) and Sharrard (59) analyzed all meniscectomies performed on subjects aged 15 to 64 years at five hospitals around Sheffield in the United Kingdom during the period 1958 to 1960 . The total number was 957 , of which $605(63 \%)$ had been performed on miners and $352(37 \%)$ on workers other than miners. By way of comparison all the appendectomies performed during the same period were analyzed. The total number was $365(34 \%)$ for the miners and 710 $(66 \%)$ for the nonminers. Among the 605 miners who had undergone meniscectomy, 150 were interviewed to

Table 4. Bursitis of the knees (\%) and occupation.

\begin{tabular}{|c|c|c|c|c|c|c|c|c|}
\hline Author & Outcome & $\begin{array}{l}\text { Participants } \\
\text { (N) }\end{array}$ & $\begin{array}{c}\text { Age } \\
\text { (years) }\end{array}$ & Type of work & Exposure & Bursitis $P$ & $\begin{array}{l}\text { Prevalence } \\
\text { ratio }\end{array}$ & $\begin{array}{l}\text { Significant } \\
(P<0.05)\end{array}$ \\
\hline Kivimäki et al (38) & $\begin{array}{l}\text { Self- } \\
\text { reported }\end{array}$ & $\begin{array}{l}168 \\
146\end{array}$ & $25-49$ & $\begin{array}{l}\text { Floor and carpet laying } \\
\text { Paintinga }\end{array}$ & $\begin{array}{l}\text { Kneeling: carpet and floorlayers } \\
42 \% \text { and painters } 3 \%\end{array}$ & $\begin{array}{r}19.0 \\
2.0\end{array}$ & 9.5 & Yes \\
\hline $\begin{array}{l}\text { Kivimäki (56) } \\
\text { Myllymäki et al (57) }\end{array}$ & Ultrasonic & $\begin{array}{l}96 \\
72\end{array}$ & $25-49$ & $\begin{array}{l}\text { Floor and carpet laying } \\
\text { Painting }\end{array}$ & $\begin{array}{l}\text { Kneeling: carpet and floorlayers } \\
42 \% \text { and painters } 3 \%\end{array}$ & $\begin{array}{l}5.8 \\
0\end{array}$ & - & Yes \\
\hline $\begin{array}{l}\text { Thun et al ( } 42) \\
\text { Tanaka et al (55) }\end{array}$ & $\begin{array}{l}\text { Self- } \\
\text { reported }\end{array}$ & $\begin{array}{r}112 \\
42 \\
243\end{array}$ & $19-87$ & $\begin{array}{l}\text { Floor and carpet laying } \\
\text { Terrazzo setting } \\
\text { Millwrighting and bricklaying }\end{array}$ & $\begin{array}{l}\text { Kneeling with use of knee } \\
\text { kicker, kneeling and seldom } \\
\text { kneeling (employed } 1-60 \text { years) }\end{array}$ & $\begin{array}{r}20.0 \\
11.2 \\
6.2\end{array}$ & $\begin{array}{l}3.2 \\
1.8 \\
1.0\end{array}$ & Yes \\
\hline Von Nauwald (41) & $\begin{array}{l}\text { Self- } \\
\text { reported }\end{array}$ & $\begin{array}{l}101 \\
74\end{array}$ & $35-63$ & $\begin{array}{l}\text { Pipe fitting } \\
\text { Other without kneeling work }\end{array}$ & $\begin{array}{l}\text { Kneeling and squatting, } \\
\text { no knee-bending work } \\
\text { (employed in average } 25 \text { years) }\end{array}$ & $\begin{array}{c}43.7(r) 35.6(l) \\
0\end{array}$ & - & Yes \\
\hline Partridge et al (54) & $\begin{array}{l}\text { Self- } \\
\text { reported }\end{array}$ & $\begin{array}{l}169 \\
689\end{array}$ & $25-64$ & $\begin{array}{l}\text { Floor molding } \\
\text { Other foundry working }\end{array}$ & $\begin{array}{l}\text { Kneeling, } \\
\text { heavy lifting under hot temperature }\end{array}$ & $\begin{array}{l}8.3 \\
0.7\end{array}$ & $\begin{array}{r}11.9 \\
1.0\end{array}$ & Yes \\
\hline
\end{tabular}

a Reference group in the study. 
obtain a description of their normal work posture. For $62 \%$ the daily work was predominantly done kneeling or crawling, $34 \%$ walked or stood, and $4 \%$ squatted. Among the subjects who normally worked in a kneeling, squatting or crawling position, $76 \%$ had gotten their meniscal lesion in this position. The symptoms generally occurred when the worker had to jump up from his knees and turn to one side, for instance, in order to avoid being hit by something falling from the ceiling. Among the subjects whose daily work was done in a walking or standing position, 92\% had gotten their meniscal lesion in this position. The meniscal lesion had occurred in the squatting position in $9 \%$ of the 150 miners.

In his physical examination of 101 pipe fitters and 74 referents, Von Nauwald (41) found signs of right and left meniscal lesion in $11.8 \%$ and $6.9 \%$ of the pipe fitters, respectively. None of the referents showed any signs of meniscal lesion.

In their study on 168 carpet and floor layers and 146 painters, Kivimäki et al (38) found that $10 \%$ of the carpet and floor layers and $5 \%$ of the painters had had a meniscal lesion diagnosed by a physician. The difference was not statistically significant. In both groups $6 \%$ stated having undergone knee surgery.

\section{Discussion}

\section{Methodological quality of the studies}

Potentially relevant studies were searched for in international computer data bases, in the data base of the library of the Danish Factory Inspectorate, and from references in the literature procured for purposes of the present review. Computer-based searches alone yield less than two-thirds of the relevant studies identified from other studies (62). We reviewed several potentially relevant studies identified from sources other than the computerbased searches. In the final selection of studies, however, only four references had not been identified in these searches $(44,48,51,52)$.

Only studies published in English, German, or one of the Scandinavian languages were considered for inclusion. This limitation may have excluded some relevant studies. In the computer-based searches, however, very few references in other languages emerged.

It is generally accepted that negative studies are less likely to be published than positive ones. This publication bias, in our opinion, is more likely when a study is not well designed. Actually, all of the studies considered as being of "poor" quality in the present review reported positive associations. We assume that most well-designed hypothesis testing studies are published even if negative. If so, such studies should not only be considered as the more important owing to their superi- or quality, but also because publication bias is less likely for good studies.

The quality assessment of the studies revealed deficiencies in several studies, the more common being a poor description of participation rates, small sample sizes, insufficient control of confounding, poorly defined outcome criteria, no blinding of outcome assessment, and a poor description of exposure.

The method of evaluating the "overall quality" of a study by scoring a number of items on different aspects of quality and summing the scores should be considered with some reservation. The final classification depends on the specific items evaluated, on the number of items, on the scores attached to each of the items, and on the way the scores are summed. For example the study of Kivimäki et al (38) received a high score since it fulfilled almost all of the quality aspects included in the evaluation. This ranking was justified for the bursitis part of the study but questionable for the osteoarthrosis part, since the age range of the material was only 25 to 49 years.

Osteoarthrosis and work-related osteoarthrosis of the knee is more prevalent in older age groups. The inclusion of a substantial proportion of young subjects will attenuate any effect of work and thus reduce the power of the study, especially when the study does not include older subjects. These aspects were not scored in the quality evaluation. And even if they had been, the final score of the study by Kivimäki et al (38) would have been high since most of the other quality aspects of the study were positively evaluated. For the other studies, however, the final quality classification was in good agreement with the authors' general opinion of the quality of the studies.

\section{Knee osteoarthrosis}

Knee osteoarthrosis is defined as a disease affecting the articular cartilage and the underlying subchondral bone tissue. The first pathological manifestation is loss of cartilage. When this loss has reached a certain size, it can be seen in an $X$ ray as a narrowing of the joint space. In addition, $X$ rays will reveal bone changes with sclerosis of the underlying bone tissue, osteophytes, and bone cysts.

Kellgren \& Lawrence (63) established the commonly used radiographic criteria for diagnosing knee osteoarthrosis, graded from 0 to 4 on the basis of the degree of changes. In most of the studies, knee osteoarthrosis was classified on the basis of the radiological findings (tables 2 and 3). In seven studies $(4,9,38-40,48,50)$ the criteria established by Kellgren \& Lawrence (63) were used. One study (49) employed Ahlbäck's criteria, according to which knee osteoarthrosis is graded from 0 to 3 for narrowing of the joint space and sclerosis and from 0 to 5 for the degree of severity of osteophytes (64). 
Three studies $(6,43-46)$ used the authors' own classification with a description of the criteria. Vingård et al (51-53) employed the diagnosis at hospitalization or application for early retirement pension in the studies. The criteria of a diagnosis of knee osteoarthrosis were not reported, but it must be presumed that they included a radiological examination of the knees. In the study by Thun et al (42) the diagnosis was based on answers to a questionnaire.

The difference between the classification criteria possibly explains some of the large differences between the prevalences reported in the studies. Thus radiological knee osteoarthrosis (all degrees) was present in $20 \%$ of the painters aged $24-64$ years (mean age 42 years) in the study by Wickström et al (6) whereas $41 \%$ of painters aged 25-49 years (mean age 39 years) had knee osteophytes in that by Kivimäki et al (38). A correlation between type of work and development of knee osteoarthrosis (all degrees) was demonstrated in all the studies and severe knee osteoarthrosis in three of six studies on kneeling and squatting work. A correlation was found in four of the eight studies on heavy physical work. Knee osteoarthrosis occurred predominantly after many years of exposure (more than 10 years) and in the age group $>45-50$ years.

The prevalence ratios for the development of radiological knee osteoarthrosis (all degrees) in occupations with kneeling or squatting work were between 1.4 and 4.1. As to heavy physical work, the prevalence ratio was between 1.4 and 3.4 in three studies; in one it was 14.3; and in four there was no significant correlation (prevalence ratio $=1.9,1.6,1.1$, and 0.7 ).

The risk of knee osteoarthrosis increases with age from being negligible at the age of 25 years to between $20 \%$ and $40 \%$ at about 75 years of age $(4,8)$. In studies on knee osteoarthrosis, therefore, it is essential that the study population include subjects above $45-50$ years of age. In the study by Kivimäki et al (38) the study group was relatively young, 25-49 years, and this low age may explain that the authors failed to demonstrate any correlation between severe knee osteoarthrosis and knee load.

The studies were divided into kneeling or squatting work and heavy physical work. The classification was made on the basis of an evaluation of the exposure reported in the studies and on the basis of our own evaluation of the occupation in question. In several of the occupations the exposure was mixed. Thus the work of floor layers involves heavy lifting and that of shipbuilders has varying degrees of kneeling and squatting work together with heavy lifts, depending on the occupational group $(38,45,46)$.

Most of the studies gave a simplified description of the exposure (eg, by using occupational codes as a measure). Only two studies $(6,38)$ employed video recording of the work practices in the study and reference groups. In a case-referent study (50) the exposure was based on the individual subject's assessment of the physical load. This procedure may give rise to information bias leading to overestimation of the risk.

The studies did not render it possible to describe a real dose-response correlation between the degree of exposure and the development of knee osteoarthrosis. In the study by Enderlein \& Kasch $(45,46)$, there seemed, however, to be a higher frequency of knee osteoarthrosis, the greater the extent of kneeling work when judged from the number of subjects with keratosis on the knees. Some of the studies $(6,38)$ comprised only subjects who were active at the time of study. In all probability this design factor involves a selection bias with underestimation of the risk of knee osteoarthrosis in occupations exposing the knees.

Taking into consideration possible sources of error, a joint evaluation of the reviewed studies that were controlled affords reasonable grounds for the assertion that occupational exposure of the knee in the form of kneeling and squatting work or heavy physical work is a risk factor for developing knee osteoarthrosis.

It is obvious that occupational load on the knees can be compared with loads from sports activities. Many types of sport (eg, football, running, and jumping) can induce acute joint lesions, among them, lesions of the meniscus and the ligaments. Major joint lesions in connection with sports are a well documented cause of knee osteoarthrosis (8). On the other hand, it must be considered unclarified whether sports activities that expose the knees induce an increased risk of knee osteoarthrosis if there has been no previous acute major knee lesions. Many studies of this problem have been uncontrolled, with a short follow-up time or with a high proportion of subjects under 50 years of age. [See the review by Felson (8).]

In occupations exposing the knees there may also be an increased risk of acute knee lesions in connection with jumping from one level to another or walking on uneven ground. Only one study $(45,46)$ controlled for acute knee lesions. This study confirmed that previous acute knee trauma was a risk factor for knee osteoarthrosis, but it also showed an increased prevalence of knee osteoarthrosis among subjects with work involving knee load but without previous acute major knee trauma.

The pathogenesis of knee osteoarthrosis in relation to work loads on the knees has not been clarified. One hypothesis is that knee osteoarthrosis is caused by a reduction of the blood flow through the bone owing to increased intraarticular pressure (65). In the standing position, the weight on either knee corresponds to $40 \%$ of body weight. Biomechanical calculations have shown that the pressure on the knee joint is increased to two to four times the body weight during normal walking and to 
six times during stair climbing (66-68). We have not been able to trace studies illustrating the intraarticular pressure during exposure to the knees in the form of kneeling and squatting work or heavy physical work. During kneeling approximately $70 \%$ of the body weight rests on a few cubic centimeters of the tibia and the patella (17). Obviously increased intraarticular pressure must be involved. Pressure will also be increased during heavy physical work.

Another hypothesis is that subchondral microfractures may induce osteoarthrosis (69). Such microfractures are considered to occur when physical load exceeds a critical level, the size of which is not known. Trained sportsmen have greater muscular strength and will generally limber up before starting real activity. This habit may result in sportsmen being less exposed to microfractures at a certain load as compared with the less trained worker who does not make any preparation before starting work. A possible difference in the risk of knee osteoarthrosis for sportsmen and workers with a comparable load on the knees may thus be explained by differences in physical condition and limber-up before the exposure. When workers and sportsmen are compared with regard to the risk of knee osteoarthrosis in relation to exposure, it should, however, be borne in mind that the exposures to the knees are so qualitatively different that there is probably no point in speaking about a directly comparable exposure.

Future investigations of the relation between occupational exposure and knee osteoarthrosis should especially focus on more precise measures of exposure. Since the period of latency for the development of knee osteoarthrosis is long, it is essential that the study group predominantly consists of subjects over 50 years of age, just as it is important to include subjects who have stopped work exposing the knees.

In addition, the pathogenesis of osteoarthrosis induced by work exposing the knees should be investigated.

\section{Bursitis}

The following bursae are located on the anterior part of the knee: (i) the prepatellar bursa, which is subcutaneous and located in front of the distal part of the patella, (ii) the subcutaneous infrapatellar bursa, located in front of the patellar ligament distal to the patella, and (iii) the deep infrapatellar bursa, located just behind the patellar ligament. Aseptic bursitis may develop in all three bursae. Bursitis has been described for workers with kneeling work and is often called "housemaid's knee" or "carpet layer's knee" (70).

All five studies revealed a higher prevalence of bursitis in occupational groups with kneeling work relative to groups without such work. An increased prevalence of bursitis was found for floor and carpet layers by three studies, in pipe fitters and terrazzo setters in one, and in floor molders in another.

One of the studies on carpet and floor layers employed video recording of the work practices, which showed that the workers were kneeling about $40 \%$ of the time (38). The proportion of kneeling work was not determined for any other occupational group.

The prevalence ratio for bursitis was between 3.2 and 9.5 for carpet and floor layers and between 1.8 and 11.9 for the other occupational groups with kneeling work. Thus a correlation between kneeling work and the development of pre- or infrapatellar bursitis is well documented.

Bursitis is presumably caused by an irritation of the bursa owing to direct pressure on it in the kneeling position. If knee protectors are used, the pressure will be distributed over a greater area of the knee (17). The direct load on the bursae will thereby be reduced with a consequently reduced risk of developing bursitis. Bursitis is a less serious disorder as compared with knee osteoarthrosis, and it will therefore be a less likely reason for leaving one's trade to find other work.

\section{Meniscal lesions}

Meniscal lesions may limit flexion and extension of the knee joint and the knee may lock. The lesions are generally induced by forced rotation while the knee is semiflexed or flexed (71). The lesions are very often a result of acute trauma (eg, during skiing). Lesions occur far more often in the medial than in the lateral meniscus, except in football players, for whom the two types occur equally often (71). Meniscal lesions have been reported to occur as a result of both acute trauma and kneeling or squatting work. In Germany, meniscal lesions in miners have been recognized as being work-related for more than 40 years $(34,43)$. In Denmark, meniscal lesions occurred during work in the squatting position in confined work spaces are recognized as an occupational disease (72).

Our search for literature revealed very few controlled studies that suggested a correlation between occupation and meniscal lesion. None of them controlled for the effect of sports activities, previous knee trauma, or trauma that occurred during work. Several of the uncontrolled studies were of an early date and predominantly concerned meniscal lesions in miners. It cannot be determined whether meniscal lesions are traumatic or a result of kneeling or squatting work during a long period. Sharrard \& Liddell (58) and Sharrard (59) reported, however, that most meniscal lesions were traumatic, being caused by a twist of the knee.

It can be concluded that the data are insufficient for evaluating a correlation between kneeling and squatting work and the development of meniscal lesion. 


\section{Acknowledgments}

This work was supported by the Statistical Consulting Service of the Danish Medical Research Council and the Danish Physiotherapist Research Foundation.

\section{Referenwces}

1. Stock SR. Workplace ergonomic factors and the development of musculoskeletal disorders of the neck and upper limbs: a meta-analysis. Am J Ind Med 1991;19:87-107.

2. Riihimäki H. Low-back pain, its origin and risk indicators. Scand J Work Environ Health 1991;17:81-90.

3. Ørhede E, Nord-Larsen M, Burr H, Nielsen J. Lønmodtagernes arbejdsmiljø: bind 1-2. Copenhagen: Arbejdsmiljøfondet, 1990.

4. Anderson J, Felson DT. Factors associated with osteoarthritis of the knee in the first national health and nutrition examination survey (HANES I). Am J Epidemiol 1988;128(1):17989.

5. Felson DT, Naimark A, Anderson J, Kazis L, Castelli W, Meenan RF. The prevalence of knee osteoarthritis in the elderly. Arthritis Rheum 1987;30(8):914-8.

6. Wickström G, Hänninen K, Mattsson T, Niskanen T, Riihimäki $\mathrm{H}$, Waris $\mathrm{P}$, et al. Knee degeneration in concrete reinforcement workers. Br J Ind Med 1983;40:216-9.

7. Lawrence JS, Molyneux MK, Dingwall-Fordyce I. Rheumatism in foundry workers. Br J Ind Med 1966;23:42-52.

8. Felson DT. Epidemiology of hip and knee osteoarthritis. Epidemiol Rev 1988;10:1 - 28

9. Kellgren JH, Lawrence JS. Osteoarthrosis and disk degeneration in an urban population. Ann Rheum Dis 1958;17:38897.

10. Felson DT, Naimark A, Anderson J, Walker AM, Meenan RF. Obesity and knee osteoarthritis: the Framingham study. Ann Intern Med 1988;109:18-24.

11. Appel H. Late results after meniscectomy in the knee joint: a clinical and roentgenologic follow-up investigation. Acta Orthop Scand 1970; suppl 133:6-111.

12. Allen PR, Denham RA. Late degenerative changes after meniscectomy: factors affecting the knee after operation. J Bone Joint Surg 1974;66:666-71.

13. Berg M, Sandén $\AA$, Torell G, Järvholm B. Persistence of musculoskeletal symptoms: a longitudinal study. Ergonomics 1988;31(9):1281-5.

14. Bergenudd $H$, Nilsson $B$, Lindgärde $F$. Knee pain in middle age and its relationship to occupational work load and psychosocial factors. Clin Orthop 1989;245:210 - 5.

15. Bergenudd $H$. Knee pain in middle age and its relation to occupational and psychosocial factors. In: Bergenudd $\mathrm{H}$, editor. Talent, occupation and locomotor discomfort. Malmö (Sweden): Department of Orthopaedics, Malmö general Hospital, Lund University, 1989:62-74.

16. Brulin C, Jonsson B, Karlehagen S. Besvär i rörelsesorganen bland bangårdspersonal: en deskriptiv epidemiologisk studie [Musculoskeletal disorders among railway staff]. Stockholm: Arbetarskyddsverket, 1985. Arbete och hälsa 37. English summary.

17. Ekström H, Engholm G, Nyquist B, Wallenquist A. Knäbesvär som arbeitsmedicinskt problem [Knee disorders as an occupational problem]. Stockholm: Bygghälsans forsknings- stiftelse, 1983.

18. Wallenquist $\mathrm{A}$. Preventing of knee disorders in construction work requiring kneeling. In: Osterholz U, Karmaus W, Hullmann B, Ritz B, editors. Work-related musculoskeletal disorders: proceedings of an international symposium. Projektträger "Humanisierung des Arbeitslebens". Tagungsbericht. $\mathrm{Tb} 48$. Hamburg, Bonn: University Hospital Eppendorf, Institute of Medical Sociology, 1987:435-45.

19. Holmström E. Musculoskeletal disorders in construction workers related to physical, psychosocial and individual factors [thesis]. Lund (Sweden): Department of Physical Therapy, Lund University, 1992.

20. Hunting KL, Weich LS, Cuccherini, Seiger LA. Musculoskeletal symptoms among electricians. Am J Ind Med 1994;25: 149-63.

21. Kannus $P$, Järvinen $M$. Incidence of knee injuries and the need for further care: a one-year prospective follow-up study. J Sports Med Phys Fitness 1989;29(4):321-5.

22. Sokas RK, Spiegelman D, Wegman DH. Self-reported musculoskeletal complaints among garment workers. Am J Ind Med 1989:15:197-206.

23. Stålhammar HR, Leskinen TPJ, Kuorinka IAA, Gärtner KH, Luopajärvi $\mathrm{T}$, Rautenberg $\mathrm{K}$, et al. Postural, epidemiological and biomechanical analysis of luggage handling in an aircraft luggage compartment. Appl Ergon 1986; 17(3):177—83.

24. Torell G, Sandén A, Järvholm B. Musculoskeletal disorders in shipyard workers. J Soc Occup Med 1988;38:109-13.

25. Undeutsch K, Küpper R, Löwenthal I, Gärtner KH, Luopajärvi T, Karvonen MJ, et al. Arbeitsmedizinische Untersuchungen über Ladearbeiten auf einem Grossflughafen. Int Arch Occup Environ Health 1982;50:59-75.

26. Wells JA, Zipp JF, Schuette PT, McEleney J. Musculoskeletal disorders among letter carriers. J Occup Med 1983;25(11): $814-20$.

27. Adamson WAD. Injuries of the cartilage in miners. Edinburgh Med J 1946;53(2):37-48.

28. Atkins JB. Internal derangement of the knee joint in miners. Br J Ind Med 1957;14:121-6.

29. Holibkova A, Machálek L, Holibka R, Chromek Z. Lesions of the knee joint menisci in miners. Acta Univ Palacki Olomuc Fac Med 1989;123:147-68.

30. Watkins JT, Hunt TA, Fernandez RHP, Edmonds OP. A clinical study of beat knee. Br J Ind Med 1958;15(2):105—9.

31. Anderson JAD: Arthrosis and its relation to work. Scand J Work Environ Health 1984;10:429 - 33 .

32. National Institute for occupational Safety and Health (NIOSH). NIOSH alert, request for assistance in preventing knee injuries and disorders in carpet layers. Cincinnati $(\mathrm{OH})$ : NIOSH, Public Health Service, US Department of Health and Human Services, 1990. DHHS (NIOSH) publication, no 90104 ,

33. Bhattacharya A, Mueller M, Putz-Anderson. Traumatogenic factors affecting the knees of carpet installers. Appl Ergon 1985;16(4):243-50.

34. Hamacher E. Die Berufskrankheit "Meniscusschäden" (BKNr. 21 02) - Entstehungsgeschichte und Fortentwicklung nach $\$ 551$ Abs.2 RVO. Arbeitsmed Sozialmed Praeventivmed 1988;23:115-7.

35. Hotz P, Söderström D, Mazzocato C, Holtz J, Boillat MA. Musculoskeletal and skin disorders in a population of floorlayers. Soz Präventivmed 1991;36:34-8.

36. Von Pressel G. Die BK 2102 "Meniskusschaden" nach der Neuregelung: Hinweise für die Begutachtung. Arbeitsmed Sozialmed Praventivmed 1988;23:303-8. 
37. Lawrence JS. Rheumatism in cotton operatives. Br J Ind Med 1961;18:270-6.

38. Kivimäki J, Riihimäki H, Hänninen $K$. Knee disorders in carpet and floor layers and painters. Scand J Work Environ Health 1992;18:310-6.

39. Kellgren JH, Lawrence JS. Rheumatism in miners, part II: Xray study. Br J Ind Med 1952;9:197-207.

40. Lawrence JS. Rheumatism in coal miners, part III: occupational factors. Br J Ind Med 1955;12:249-61.

41. Von Nauwald G. Untersuchungen zur Häufigkeit professioneller Kniegelenkserkrankungen bei älteren Rohrschlossern im Hochseeshiffbau. Beitr Orthop Traumatol 1986;33:124 8.

42. Thun M, Tanaka S, Smith AB, Halperin WE, Lee ST, Luggen ME, et al. Morbidity from repetitive knee trauma in carpet and floor layers. Br J Ind Med 1987;44:611 - 20 .

43. Greinemann H. Argumente gegen die Anerkennung von Kniegelenkarthrosen nach Berufsbelastung als Berufskrankheit. Unfallchirurgie 1988;91:374—80

44. Greinemann H. Praedestinieren Kniescheibenhochstand, Knieund Kniescheibenfehlformen, sowie Beinachsenfehlstellungen bei Kniebelastenden Berufen zu vorzeitigen verschleissshäden [Forschungsbericht]. Dortmund: Bundesanstalt für Arbeitsschutz, 1983.

45. Enderlein G, Kasch J. Modellierung von Dosis-Wirkungsbezeihungen für expositionsabhängige Veränderungen am Bewegungsapparat. Z Gesamte Hyg 1989;35(4):215-8.

46. Kasch J, Enderlein G. Kniegelenkschäden im Schiffbau. Beitr Orthop Traumatol 1986,33:487-94.

47. Lawrence JS, Molyneux MK Dingwall-Fordyce I. Rheumatism in foundry workers. Br J Ind Med 1966;23:42 - 52.

48. Partridge REH, Duthie JJR. Rheumatism in dockers and civil servants: a comparison of heavy manual and sedentary workers. Ann Rheum Dis 1968;27:559_67.

49. Lindberg H, Montgomery F. Heavy labor and the occurrence of gonarthrosis. Clin Orthop 1987;214:235-6.

50. Kohatsu ND, Schurman DJ. Risk factors for the development of osteoarthrosis of the knee. Clin Orthop 1990;261:242-6.

51. Vingård E, Alfredsson L, Evy F, Christer H. Risken för män $\mathrm{i}$ fysiskt tunga yrken att förtidspensioneras på grund av sjukdomar $\mathrm{i}$ rörelsesapparaten [The risk of receiving disability pension due to musculoskeletal disorders in men with physically strenuous occupations]. Stockholm: Arbetarskyddsverket, 1991. Arbete och hälsa 41. English summary.

52. Vingård E, Alfredsson L, Evy F, Christer H. Disability pensions due to musculo-skeletal disorders among men in heavy occupations: a case-control study. Scand J Soc Med 1992,20: $31-6$.

53. Vingård E, Alfredsson L, Goldie I, Hogstedt C. Occupation and osteoarthrosis of the hip and knee: a register-based cohort study. Int J Epidemiol 1991;20(4):1025-31.

54. Partridge REH, Anderson JAD, McCarthy MA, Duthie JJR. Rheumatic complaints among workers in iron foundries. Ann Rheum Dis 1968;27:441—53.
55. Tanaka $S$, Halperin WE, Smith $A B$, et al. Skin effects of occupational kneeling. Am J Ind Med 1985;8:341-9.

56. Kivimäki J. Occupationally related ultrasonic findings in carpet and floors layers' knees. Scand J Work Environ Health $1992 ; 18: 400-2$.

57. Myllymäki T, Tikkakoski T, Typpö T, Kívimäki J, Suramo I. Carpet-layer's knee: an ultrasonographic study. Acta Radiol 1993;34(5):496-9.

58. Sharrard WJW, Liddell FDK. Injuries to the semilunar cartilages of the knee in miners. Br J Ind Med 1962;19:195-202.

59. Sharrard WJW. Pressure effects on the knee in kneeling miners. Ann R Coll Surg Engl 1965:309-24.

60. Kristensen TS. Cardiovascular diseases and the work environment: a critical review of the epidemiologic literature on nonchemical factors. Scand J Work Environ Health 1989;15: 165-179.

61. Koes BW, Bouter LM, Beckerman H, van der Heijden GJMG, Knipschild PG. Physiotherapy exercises and back pain: a blinded review. Br Med J 1991;302:1572-6.

62. Sacks HS, Berrier J, Reitman D, Ancona-Berk VA, Chalmers TC. Meta-analysis of randomized controlled trials. New Engl J Med 1987;316:450—5.

63. Kellgren JH, Lawrence JS. Atlas of standard radiographs; vol 2 (The epidemiology of chronic rheumatism). Oxford: Blackwell Scientific Publications, 1963.

64. Ahlbäck S. Osteoarthrosis of the knee: a radiographic investigation. Acta Radiol 1968: suppl 277.

65. Arnoldi CC, Reimann I. The pathomechanism of human coxarthrosis. Acta Orthop Scand 1979: suppl 181.

66. Morrison JB. The mechanics of the knee joint in relation to normal walking. J Biomech 1970;3:51—61.

67. Dahlkvist NJ, Mayo P. Forces during squatting and rising from a deep squat. Eng Med 1982;1182:69—76.

68. Andriacchi TP, Andersson GBJ, Fermier RW, Stern D, Galante JO. A study of lower-limb mechanics during stair-climbing. J Bone Joint Surg 1980;62A(5):749—57

69. Radin EL, Parker HG, Pugh JW, Steinberg RS, Paul IL, Rose RM. Response of joints to impact loading-III: relationship between trabecular microfractures and cartilage degeneration. J Biomech 1973,6:51-7.

70. Hunter D. Diseases of occupations. London: Hodder and Stoughton, 1978.

71. Caillet R. Knee pain and disability. Philadelphia (PA): FA Davis Company, 1992.

72. Bekendtgørelse om fortegnelse over erhvervssygdomme i medfør af lovgivning om forsikring mod følger af arbejdsskade: arbejdsskadestyrelsens bekendtg ørelse $\mathrm{nr} 54$ af 19 januar 1995 [Consolidated act of list of occupational diseases in persuance of legislation on insurance against the industrial injuries: consolidated act no 54 of january 19th, 1995]. Copenhagen: The National Board of Industrial Injuries, 1995.

Received for publication: 2 October 1995 